Joseph Paczoski was born on December 8, 1864, in Bialogrodka (Wolhynia). He was educated at the Agricultural School in Human (Ukraine) and afterwards studied and was assistant under the well-known Prof. Schmalhausen at the University of Kief (188894). He then held successively various posts. $\mathrm{He}$ was custodian of the Botanical Garden of St. Petersburg (1894-95), assistant at the Agricultural College of Dublany near Lw6w (south-eastern Poland) (189597), director of the Natural History Museum at Cherson (Ukraine) (1907-20), founded by himself, director of the Steppes Preservation of Ascania Nova (192223). After the outbreak of revolution in Russia, Paczoski refused the very good facilities for scientific work offered him by the Soviet Government and left Russia for Poland. There he was appointed director of the National Park in Bialowieza (1923-28) consisting of primeval forest. At the same time he was professor of taxonomy and plant-geography at the University of Poznan. During about fifty strenuous years he published more than two hundred scientific papers and articles. These works have earned him a place among the best-known men of science in Europe.

When engaged in the study of the flora and of plant-geography he spent most of his time on excursions to many places ranging from the Baltic to the Adriatic Sea and eastwards to the Volga.

No other Polish botanist, and only a few from other countries, have succeeded in investigating such wide areas as Prof. Paczoski. He was considered to be the most outstanding investigator of the flora of south-eastern Europe. Prof. Paczoski was the originator of a new branch of botany, phytosociology. Until a few years ago men of science of western Europe had to refer in phytosociology to the treatise by M. R. Harper, "The New Science of Plant Sociology" (1917). Still more recently Russian botanists with their tremendous enthusiasm have occupied the first place in the development of phytosociology, after having rightly acknowledged the great merits of Prof. Paczoski, the Polish pioneer in this field (W. W. Alechin: "Wann und wo ist die Phytosoziologie entstanden ?", Botaniska Notiser, Lund, 1924). It is more than fifty years since Prof. Paczoski published his work "Stages in Flora Evolution" (Russian, Wiestnik Jestiestwoznanja, St. Petersburg, 1891). There he laid down the principal outlines of phytosociology so clearly that to-day nothing more can be added or abstracted from these. The term 'phytosociology' was used for the first time in his next work "The Social Life of Plants" (published in the Polish magazine Wszechswiat, Warsaw, 1896). By giving the outlines of and a name to the new science Prof. Paczoski deserves a permanent place in the history of phytosociology. As acknowledgment of his great merits, the Polish Botanical Society reprinted his "Social Life of Plants" in the "Biblioteka Botaniczna", vol. 2, Cracow, 1930, published in Polish and English. The term 'phytosociology' has been used by the following authors in chronological order: J. Paczoski in 1896, P. Krylow in 1898, W. Sukaczew in 1915, M. Harper (United States) in 1917, in Scandinavia and Western Europe in 1919.

Researches made in Bialowieza directed his attention to the relation between the number of trees and diameter of the trees at $1.3 \mathrm{~m}$. (to about $4 \mathrm{ft} .3 \mathrm{in}$.) in pure and mixed woods respectively. Paczoski's curves for the primeval and thinned forests are based on these measurements. These methods have been termed hy Paczoski "biological structure of forests".
After further investigation they will be of practical importance in forestry. Results have been published in the Polish Forestry Society's Journal Sylwan printed in Lwow, and in the standard work "Forest of Bialowieza". In 1930 Paczoski was sent by the University of Poznan to Yugoslavia and Bulgaria for special forest investigations. His very interesting results were published in Sylwan.

Prof. Paczoski's death is a serious loss not only to Polish science but also to the scientific community throughout the world.

S. B

\section{The Right Hon. Lord Glanely}

The Right Hon. Lord Glanely, whose death occurred on June 28 as a result of enemy action, was president of the Court of Governors of the University College of South Wales and Monmouthshire. A Cardiff shipping magnate and head of the Tatem Shipping Company, he had always maintained a special interest in University College, Cardiff. After the War of 1914-18, when a special appeal was launched for the completion of the buildings on the new site in Cathays Park, he made a magnificent donation of $£ 100,000$ to that fund. This was allocated to the provision of the "Tatem Chemical Laboratory" and to the erection of a wing of the College to be devoted to the study of agriculture, a subject in which the late Lord Glanely was specially interested. This wing now houses the Advisory Departments of Agricultural Zoology, Agricultural Botany and Veterinary Science. In 1930 Lord Glanely made a gift of $£ 2,000$ to found two scholarships in memory of his wife, to be awarded in the first place to the children of parents who are or have been employed at or about Cardiff Docks. In this way he indicated his special interest in the welfare of the workers in the industry from which he derived his fortune. At the time of his death Lord Glanely was serving his third five-year term of office as president of University College, Cardiff. The College mourns the loss of a generous benefactor whose sympathy for, and interest in, its progress had extended over twenty. five years, the most difficult and important in its history.

\section{WE regret to announce the following deaths :}

Prof. Raymond Dodge, emeritus professor of psychology at Yale University, member of the U.S. National Academy of Sciences and president in 1916-17 of the American Psychological Association, on April 8, aged seventy-one.

Mr. E. C. Groesbeck, metallurgist of the Division of Metallurgy of the U.S. Bureau of Standards, on May 8, aged sixty-one.

Mr. G. C. Lloyd, secretary of the Iron and Steel Institute during 1908-34, on July 10, aged eighty-one.

Mr. W. F. Reynolds, chief of the Section of Triangulation of the Division of Geodesy of the U.S. Coast and Geodetic Survey, on May 1, aged sixty-one.

Prof. John Harrison Skinner, professor of animal husbandry and dean emeritus of the School of Agriculture of Purdue University, on April 28, aged sixty-eight.

Prof. A. N. Talbot, professor of municipal and sanitary engineering in the University of Illinois, on April 3.

Prof. W. H. Young, F.R.S., formerly professor of mathematics in the University of Wales, aged seventy-eight. 